\title{
IDENTIFIKASI KHV DENGAN UJI IMMUNOFLUORESCENCE DAN IMMUNOCYTOCHEMISTRY BERDASARKAN UJI PCR POSITIF PADA INSANG IKAN KOI (Cyprinus carpio)
}

\author{
Oktarina Surfianti $^{* 1}$, Soewarno ${ }^{1}$, Gunanti Mahasri ${ }^{2}$ \\ ${ }^{1}$ Fakultas Kedokteran Hewan Universitas Airlangga \\ Kampys C Mulyosari-Surabaya, 60115 Telp. 031-5992785 \\ ${ }^{2}$ Fakultas Perikanan dan Kelautan Universitas Airlangga \\ Kampus C Mulyosari-Surabaya, 60115 Telp. 031-5911451 \\ e-mail: ${ }^{* 1}$ hr_surfi@yahoo.co.id,
}

\begin{abstract}
Abstrak
Koi Herpesvirus (KHV) menyebabkan penyakit parah dan kematian di segala usia ikan mas dan ikan koi (Cyprinus carpio) dan menyebar dengan cepat di seluruh dunia sebagai penyebab mortalitas yang sangat tinggi dengan perkiraan (80-95\%) untuk ikan koi dan ikan mas. Identifikasi KHV ini sudah dilakukan dengan metode Polymerase Chain Reaction (PCR). Tetapi, metode tersebut tidak cocok untuk pekerjaan lapangan karena belum efisien dalam hal waktu dan peralatan. Perlu ada pemeriksaan berbasis imunologis sebagai identifikasi awal (pemeriksaan dini) yang belum banyak dilakukan dan perlu dikembangkan terutama untuk pemeriksaan KHV yaitu metode Immunofluorescence sebagai pemeriksaan imunologis untuk identifikasi adanya antigen atau dengan menggunakan pewarnaan fluorescent dan immunocytochemistry menggunakan metode imuno histo (sito) kimia ensim yang bersifat spesifik dengan pewarnaan oleh zat chromogen guna mengidentifikasi antigen dalam suspensi organ insang dan darah. Tujuan dari penelitian ini adalah agar mampu mengidentifikasi KHV (Koi Herpes Virus) yang menginfeksi ikan koi (Cyprinus carpio L) menggunakan metode aplikasi Immunofluorescence serta Immunocytochemistry berdasarkan pemeriksaan menggunakan uji PCR dengan hasil positif KHV.Hasil dari kedua metode diperoleh positif untuk beberapa sampel berdasarkan positif PCR, ditandai dengan adanya pendaran oleh zat fluorescent berwarna hijau pada antigen dengan pemeriksaan metode Imunofluorescence dan adanya ekspresi zat chromogen pada antigen berwarna coklat kemerahan pada antigen dengan pemeriksaan Imunocytochemistry. Sehingga dapat disimpulkan bahwa kedua metode tersebut mampu mengidentifikasi KHV dan dapat digunakan sebagai uji pemeriksaan dini KHV berbasis imunologis.
\end{abstract}

Kata kunci: Koi Herpesvirus, Ikan koi (Cyprinus carpio), Imunofluorescence, Immunocytochemistry 


\begin{abstract}
Koi Herpesvirus (KHV) cause severe disease and death in all ages carp and koi carp (Cyprinus carpio) and spread rapidly around the world as the cause of very high mortality with estimates (80-95\%) for koi and goldfish. KHV identification has been carried out by the method of Polymerase Chain Reaction (PCR). However, these methods are not suitable for field work because it is not efficient in terms of time and equipment. There needs to be examination-based immunological as early identification (primary care physician) that has not been done and needs to be developed especially for the examination $K H V$ is the method Immunofluorescence as inspection immunological to the identification of the antigen or by using a staining fluorescent and immunocytochemistry using immuno histo (sito) chemical enzymes specific staining by the chromogen substances in order to identify the antigen in suspension gills organs and blood. The purpose of this research is to be able to identify KHV (Koi Herpes Virus) that infects koi carp (Cyprinus carpio L) using application methods Immunofluorescence and immunocytochemistry based examination using a PCR test with positive results from both methods obtained KHV.Hasil positive for multiple samples based on positive PCR, characterized by the luminescence by the green fluorescent substance with inspection methods Imunofluorescence antigens and their expression on antigen chromogen substances are reddish brown in antigen with Imunocytochemistry examination. It concluded that both methods are able to identify KHV and can be used as an early test of KHV based immunological examination.
\end{abstract}

Keywords: Koi Herpesvirus, Ikan koi (Cyprinus carpio), Imunofluorescence, Immunocytochemistry

\section{PENDAHULUAN}

Indonesia yang mempunyai dua musim yaitu musim hujan dan panas, yang menambah peluang berbagai biota untuk bertahan hidup dan tumbuh subur, baik didaratan maupun diperairan (Mashuri Masri, 2013). Akibat kondisi tersebut di atas, berbagai jenis penyakit pada ikan dapat mudah terjadi sebagai akibat adanya interaksi antara mikroorganisme yaitu parasit, jamur, bakteri dan virus yang patogen maupun non patogen dengan induk semang/inang/host dan terutama akibat dari beberapa faktor lingkungan yang kurang mendukung (Isti,2001). Salah satu penyakit yang menginfeksi ikan adalah jenis Koi Herpesvirus. Koi Herpesvirus (KHV) adalah penyakit virus yang sangat menular yang menyebabkan morbiditas dan mortalitas yang signifikan pada ikan mas (Cyprinus carpio) dan domestik ikan hias (Soliman and El-Matbouli, 2005).

Koi Herpesvirus (KHV) menyebabkan penyakit parah dan kematian di segala usia ikan mas dan ikan koi (Cyprinus carpio) dan menyebar dengan cepat di seluruh dunia. Sebagai pandangan bahwa KHV adalah penyakit terbatas pada perdagangan ikan hias sehingga dapat diminimalkan untuk mengevaluasi dampaknya terhadap budidaya di Eropa (Haenen et al, 2004).

Di Indonesia sendiri infeksi paling besar terjadi pada tahun 2001 menyebabkan penurunan produksi ikan mas nasional yang mengalami penurunan sekitar $40 \%$ selama kurun waktu 2002-2006 (Sunarto et al. 2002). Hal ini karena banyak ikan yang mati terkena serangan virus koi herpes. Sehingga terjadi kelangkaan ikan hias di pasaran, terutama ikan koi (Taukhid et al, 2004).

Beberapa pendekatan pemeriksaan atau identifikasi Koi Herpesvirus (KHV) sudah dilakukan mulai tahun 2002. KHV telah didiagnosis dengan metode Polymerase Chain Reaction (PCR). Manfaat besar PCR yaitu sebagai deteksi penyakit secara molekuler terutama penyakit viral (Cobo,2012). Salah satu penyakit viral yang dapat dideteksi dengan PCR yaitu KHV (Koi Herpesvirus)

JBP Vol. 18, No. 3, December 2016-Oktarina Surfianti 
(Ciptoroso, et al 2012). Metode ini tidak cocok untuk pekerjaan lapangan karena membutuhkan peralatan laboratorium yang tidak simpel. Dengan demikian, metode atau alat, yang mampu secara definitif mendeteksi virus dari jaringan yang terinfeksi sangat diperlukan, misalnya metode immunokromatografi kit dengan monoklonal spesifik antibodi terutama untuk kasus di lapangan (Aoki, et al. 2011).

Identifikasi KHV sudah banyak dikembangkan dan sudah banyak diteliti terutama pada ikan Cyprinids seperti dengan menggunakan metode PCR. Tetapi dalam pemeriksaan berbasis imunologis masih belum banyak dilakukan dan perlu dikembangkan terutama untuk pemeriksaan KHV. Pemeriksaan Immunocytochemistry (ICC) merupakan salah satu jenis pemeriksaan imunologis, menggunakan metode imuno histo (sito) kimia ensim yang bersifat spesifik dan bertujuan untuk membantu mendeteksi antigen dalam cairan specimen klinik yang terinfeksi oleh kuman pathogen (Warsito, 1991). Sedangkan pemeriksaan Immunofluorescence merupakan suatu jenis pemeriksaan imunologis untuk deteksi adanya antigen atau mencari lokalisasi antigen dalam jaringan atau sel specimen klinik dengan menggunakan pewarnaan fluorescent dan metode ini sudah telah banyak penelitian tahun-tahun sebelumnya di wilayah lain dan ternyata memberikan korelasi positif terhadap hasilnya (Priyambodo, 2001).

Penerapan dan penggunaan uji bioteknologi berbasis antibodi, yaitu metode immunofluorescence (IF) dan imunocytochemistry (ICC/ Imunositokimia) streptavidin biotin dalam mendeteksi protein virus KHV pada ikan koi adalah sangat penting. Mengingat identifikasi KHV berbasis antibodi masih jarang dilakukan sementara itu masih sering menggunakan uji berbasis DNA dengan kebutuhan biaya yang relatif lebih mahal, perlu waktu dan penanganan serta alat khusus. Menurut Warsito, 2013 bahwa uji berbasis antibodi ini penting guna mendukung upaya penanganan wabah KHV pada Ikan mas, ikan koi selama ini selalu terlambat dan pada kasus infeksi KHV, di lingkungan perairan sekitar dan mampu menginfeksi ikanikan lain yang peka. (Warsito dkk, 2013). Ditambahkan lagi oleh Lestari dkk, 2014 bahwa perlu adanya pengembangan teknik pemeriksaan yang cepat, tepat dan akurat dengan mengembangkan uji immunofluorescence dan immunocytochemistry / imunositokimia pada preparat apus darah dan organ insang sebagai salah satu pemeriksaan awal KHV.

\section{METODE PENELITIAN}

Pelaksanaan penelitian ini dilakukan pada bulan Nopember 2015 sampai bulan Maret 2016 di Laboratorium Imunologi Balai Karantina Ikan Pengendalian Mutu dan Keamanan Hasil Perikanan Kelas I Surabaya I. Bahan penelitian yang digunakan adalah ikan koi postif KHV berdasarkan pemeriksaan uji PCR yang diambil dari berbagai wilayah di sekitar Jawa Timur. Ikan koi diambil dari ikan yang diduga terinfeksi KHV dengan beberapa tanda klinisnya antara lain berupa insang geripis, erosi atau borok pada kulit, gerakan tak terkontrol, kulit melepuh atau kadang disertai pendarahan pada sirip ataupun pada ikan koi yang tidak menunjukkan tanda-tanda gejala klinis atau bersifat carrier.

Bahan untuk uji PCR adalah DNAzol, Alkohol absolut, master mix, ddH2O/ Nuclease free water, Agarose 2\%, Primer Mix KHV F 292 bp dan R 292 bp, DNA template kontrol negatif, DNA template kontrol positif $K H V, T A E$ buffer Ethidium bromide, $6 x$ Loading dye buffer, $100 \mathrm{bp}$ ladder DNA marker.

Bahan untuk Immunofluorescence adalah methanol, larutan buffer saline, normal goat serum, Ix PBS, Mouse Anti-Koi Herpesvirus (KHV) monoclonal antibody, goat anti-mouse Ig $G$ fluorescence conjugate, entellan neu utuk proses mounting, aquades steril.

Bahan yang digunakan untuk metode Immunocytochemistry ini antara lain methanol, larutan buffer saline, $10 \%$ hydrogen peroxide block, normal goat serum, Mouse anti-Koi 
Herpesvirus (KHV) monoclonal antibody, goat anti-mouse IgG biotin conjugate, streptavidin horseradish peroxidase, substrat-chomogen solution, counter stain (Mayer's hematoxylin, serta Entellan neu untuk proses mounting.

Peralatan yang digunakan untuk pemeliharaan ikan adalah akuarium yang digunakan sebagai tempat penampungan sementara ikan koi dari berbagai wilayah sebelum dilakukan uji PCR.

Peralatan untuk uji PCR adalah micropipet $(1-10 \mu \mathrm{l}),(50-200 \mu \mathrm{l}),(200-1000$ $\mu l)$, sarung tangan, timbangan analitik, Thermocycler (Mesin PCR), pellet pastle, hot plate, Microtube $200 \mu \mathrm{l}$ dan $1500 \mu \mathrm{l}$, Pipet Tips $(1-10 \mu \mathrm{l}),(50-200 \mu \mathrm{l}),(200-1000 \mu \mathrm{l})$, peralatan Elektroforesis dan Power Supply, vortex, UV Trans-illuminator, camera Polaroid.

Peralatan untuk uji Immunofluorescence adalah coplin jar, cover glass, incubator, mikroskop fluorescence dan objek glass. Peralatan untuk Immunocytochemistry adalah coplin jar, cover glass, incubator, lemari es, mikroskop cahaya, objek glass, timbangan analitik, dan sarung tangan.

Penelitian ini menggunakan metode eksperimental uji Immunofluorescence dan Immunocytochemistry menggunakan jaringan insang ikan koi dan menggunakan whole darah (Cyprinus carpio) yang diperoleh dari berbagai wilayah di Jawa Timur (Blitar, Malang, Kediri).

Pengujian awal dengan metode PCR sebagai uji konfirmasi awal guna mengetahui positif KHV yang akan dilanjutkan dengan uji immunofluorescence

Immunocytochemistry.

Teknik pengambilan sampel menggunakan simple random sampling yaitu mengambil secara acak sampel ikan dari berbagai wilayah yang kemudian dilakukan pemeriksaan dengan metode PCR guna mengetahui positif KHV yang akan dilanjutkan dengan uji immunofluorescence dan Immunocytochemistry.

\section{Persiapan Ikan yang Akan Diuji}

Ikan koi yang digunakan untuk proses uji diperoleh dari sentra budidaya ikan Koi di berbagai wilayah di Jawa Timur. Ikan koi ditampung sementara pada akuarium yang telah dibersihkan kemudian di lanjutkan uji PCR hingga ketemu positif KHV.

\section{Pengujian PCR}

Isolasi DNA KHV yang selanjutnya digunakan untuk uji PCR untuk menentukan ikan yang terinfeksi KHV dan selanjutnya digunakan dalam uji utama yaitu pemeriksaan menggunakan uji immunofluorescence dan imunositokimia. Adapun tahapan dalam proses pemeriksaan dengan metode PCR adalah yang pertama melakukan Ekstraksi Tri Reagent, persiapan amplifikasi dan persiapan dalam alat Thermal Cycler.

Ekstraksi TRI Reagent yang dilakukan pertama kali yaitu sampel ikan pada organ insang sebanyak 50-100 mg dipotong kecilkecil/ digerus halus dengan pisau bedah atau gunting steril. Untuk menghindari kontaminasi, setiap sampel harus diproses dengan menggunakan tempat dan alat yang berbeda. Selanjutnya sampel tersebut diekstrak DNA-nya.

Pendeteksian DNA KHV dengan teknik PCR dilakukan dengan menggunakan primer spesifik menurut Gray et al, (2002) yang telah dimodifikasi oleh Kurita, et al (2009). Primer Sphl-5 (5'GAC ACC ACA TCT GCA AGG AG 3') dan (5'GAC ACA TGT TAC AAT GGT CGC 3') akan menghasilkan amplikon seberat $292 \mathrm{bp}$.

Persiapan amplifikasi dengan menambahkan RTG PCR Bead 1 butir, Primer F290 (20 pMol) sebanyak $2 \mu 1$ dan primer R290 (20 pMol) sebanyak $2 \mu$ l. Ditambahkan template DNA sebanyak $2 \mu \mathrm{l}$. Kemudian dengan menambahkan Aquades steril sebanyak $19 \mu \mathrm{l}$. Adapun siklus amplifikasi yang digunakan yaitu dengan 1 suklus pada suhu $95^{\circ} \mathrm{C}$ selama 5 menit; 30 siklus pada suhu $95^{\circ} \mathrm{C}$ selama 30 detik, $50^{\circ} \mathrm{C}$ selama 30 detik dan $72^{\circ} \mathrm{C}$ selama 30 detik; serta 1 siklus pada suhu $72^{\circ} \mathrm{C}$ selama 30 detik, $72^{\circ} \mathrm{C}$ selama 7 menit.

Produk PCR (amplicon) dipisahkan dengan elektroforesis gel. Elektroforesis 
dilakukan pada voltase 120 volt hingga indikator warna loading dye buffer bergerak $3 / 4$ bagian dari panjang gel. Selanjutnya gel agarosa dimasukkan ke dalam larutan pewarnaan $(0.05 \%$ ethidium bromida) dalam wadah plastik sampai terendam selama 10 menit. Gel diamati dengan UV transilluminator dan dokumentasi.

\section{Pengujian Imunositokimia}

Metode Immunocytochemistry I imunositokimia dilakukan dengan menggunakan sampel darah untuk apusan dengan urutan kerja yaitu dengan mengambil darah menggunakan spuit 1cc. Satu tetes darah diletakkan diatas objek gelas dan diulas tipis. Sediaan hasil olesan darah tipis ini kemudian difiksasi kedalam larutan methanol selama 10 menit.

Sediaan selanjutnya ditetesi dengan normal goat serum dan diinkubasi pada suhu kamar selama 30 menit. Sediaan ditetesi dengan antibody primer yang berupa antiKHV Monoklonal antibody lalu inkubasi pada suhu $37{ }^{\circ} \mathrm{C}$ selama 20 menit. Kemudian sediaan dicuci dengan larutan PBS selama 10 menit, selanjutnya ditiriskan diatas kertas tissue.

Sediaan ditetesi dengan antibody sekunder dan ditambah dengan cairan biotinylated secondary antibody selama 10 menit. Sediaan dicuci menggunakan PBS selama 10 menit, kemudian ditiriskan diatas kertas tissue. Sediaan kemudian diinkubasi dengan streptavidin-peroxidase conjugate selama 5 menit. Selanjutnya sediaan dicuci lagi dengan PBS selama 10 menit, lalu tiriskan diatas kertas tissue.Selanjutnya sediaan diinkubasi dengan substrat-chromogen pada suhu kamar selama 15 menit. Kemudian sediaan dicuci dengan aquades selama 10 menit. Sediaan kemudian dilakukan counterstain hematoxylin selama 10 menit.

Dicuci dengan aquadesh dan mounting dengan entellan neu untuk pengamatan di bawah mikroskop cahaya. Hasil positif apabila dalam sediaan yang telah dilakukan pewarnaan menggunakan streptavidin-biotin akan terlihat warna coklat kemerahan/keemasan.

\section{Pengujian Immunofluorescence}

Pemeriksaan imunofluorescence adalah suatu jenis pemeriksaan imunologis untuk mendeteksi adanya antigen atau mencari lokalisasi antigen dalam jaringan atau sel specimen dengan pewarnaan florescence. Prinsip dasar pemeriksaan KHV pada ikan koi adalah dengan membuat preparat ulas dari organ insang, hati dan ginjal, yang kemudian ditetesi dengan anti-KHV fluorescent dan diinkubasi pada suhu $37^{\circ} \mathrm{C}$ selama 30 menit. Setelah dilakukan pencucian dengan larutan buffer fosfat, selanjutnya dibuat sediaan pada objek glass kemudian dilihat dengan menggunakan mikroskop fluorescence. Apabila dalam ulasan tersebut mengandung antibodi yang menyelubungi KHV maka akan tampak warna fluoresensi kehijauan. Untuk membuat kesimpulan hasil pemeriksaan KHV, maka perlu diperhatikan adalah KHV dan intensitas fluoresensi. Hasil pemeriksaan memberikan penilaian positif atau negatif (Matuscak et al., 1982; Ardana, 1987; Kunin, 1997).

Teknik pewarnaan dalam mendeteksi protein virus KHV dilakukan berdasarkan metode indirect labeling immunofluorescence. Sebelumnya dilakukan pengambilan organ insang. Kemudian insang digerus dengan pelet pastel. Selanjutnya dengan penambahan PBS $1 \mathrm{x}$ sebanyak $500 \mu \mathrm{l}$ dilakukan sentrifuge $10.000 \mathrm{rpm}$ selama 5 menit. Pelet yang telah diperoleh dari hasil ekstraksi tersebut kemudian di smear pada objek glass secara merata dan setelah itu di fiksasi dengan methanol dengan tujuan membloking antigennya.

Fiksasi dilakukan dalam larutan methanol selama 30 menit pada suhu $-20{ }^{\circ} \mathrm{C}$. Berikutnya antigen diikat dengan antibody spesifik yang tidak dilabel (unlabeled spesific antibody) sebagai antibody primer (mouse anti-KHV monoclonal antibody) dan diinkubasi sebagai ikatan antibody pertama. Sediaan kemudian diinkubasikan dengan antibody sekunder yang berlabel (Fluorochrome secondary antibody). Antibodi ini mengandung antiboi anti imunoglobulin 
hewan. Antibodi sekunder ini akan mengikat antibodi primer.

Hasil preparat positif didapatkan akibat dari reaksi antigen-antibodi kompleks (WHO 1996) yang berwarna hijau fluorescence dengan ukuran bervariasi. Hasil negatif jika tidak memberikan warna fluorescence (Dean et al, 1996).

\section{Analisa Data}

Data yang akan didapatkan dianalisa dengan menggunakan metode deskriptif kualitatif yaitu suatu cara dengan menggambarkan atau memaparkan dengan kata-kata secara jelas dan terperinci tentang sebuah kegiatan yang dilakukan dan dibandingkan dengan literature dengan menganalisa hasil berdasarkan tingkat ekspresi dari ikan uji berdasarkan metode Immunofluorescence dan Immunocytochemistry.

\section{HASIL DAN PEMBAHASAN}

Hasil pengambilan ikan yang terinfeksi di beberapa wilayah yaitu Blitar,

\begin{tabular}{|l|l|l|}
\hline No & $\begin{array}{l}\text { Asal } \\
\text { Daerah }\end{array}$ & $\begin{array}{l}\text { Gejala Klinis dan } \\
\text { patologis anatomis }\end{array}$ \\
\hline 1. & Blitar & $\begin{array}{l}\text { Erosi sirip, sisik } \\
\text { banyak yang } \\
\text { terlepas, mata } \\
\text { cekung dan nekrosis } \\
\text { serta terdapat nodule } \\
\text { putih pada insang }\end{array}$ \\
\hline 2. & Malang & $\begin{array}{l}\text { Erosi sirip ekor, } \\
\text { kongesti di sirip } \\
\text { dada, dan nekrosis } \\
\text { serta terdapat nodule } \\
\text { putih pada insang }\end{array}$ \\
\hline 3. & Kediri & $\begin{array}{l}\text { Kongesti sirip dada } \\
\text { dan hemoragi area } \\
\text { punggung }\end{array}$ \\
\hline
\end{tabular}

Malang dan Kediri didapatkan beberapa ikan terinfeksi KHV dengan dibuktikan adanya beberapa insang telah mengalami nekrosis dan beberapa gejala klinis lainnya dapat dilihat pada Tabel 1.

Tabel 3.1 Pemeriksaan gejala klinis dan patologis anatomis pada beberapa ikan koi yang diperoleh dari beberapa daerah

Ikan koi yang digunakan selama penelitian merupakan ikan sehat sebagai kontrol negatif setelah melalui konfirmasi awal dengan uji PCR dapat dilihat pada Gambar 3.1 dan ikan sakit yang menunjukkan gejala patologis anatomis sebagai kontrol positif dapat dilihat pada Gambar 3.2.
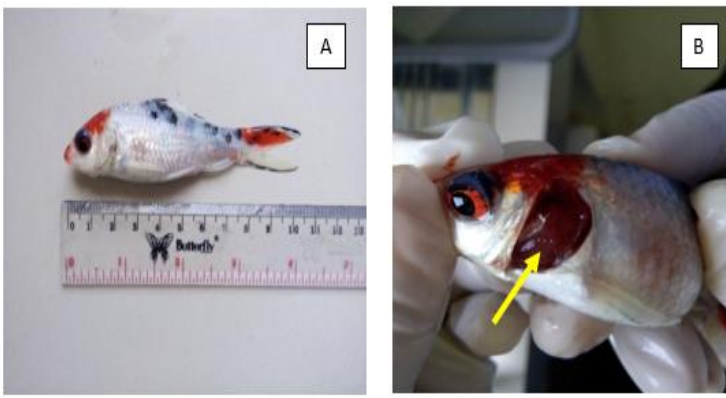

Gambar 3.1 Ikan koi sehat dengan kondisi insang berwarna merah segar, sisik lengkap, mata cembung, digunakan sebagai kontrol negatif. A Kondisi Ikan sehat dengan mata cembung, tidak terdapat luka, sisik lengkap. B. Insang tampak berwarna merah cerah.
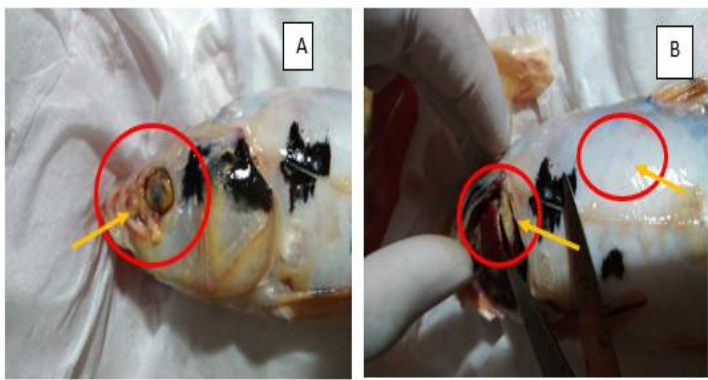
Gambar 3.2 Ikan koi terinfeksi KHV yang digunakan sebagai kontrol positif. A. mata cekung dan adanya infeksi sekunder yaitu ulcer daerah kepala, nekrosis pada lamella insang, B. sisik rontok,

\section{Pengujian Menggunakan Polymerase Chain Reaction}

Ikan koi untuk sampel penelitian dilakukan setelah ikan koi dipingsankan dengan larutan cengkeh dosis $1-5 \mathrm{cc} / 10$ liter air. Satu persatu ikan diuji dengan pengambilan organ insang. Insang diletakkan didalam tube untuk proses PCR. Prosedur Pemeriksaan KHV berdasarkan metode PCR dengan beberapa tahapan mulai dari proses ekstraksi, amplifikasi hingga elektroforesis dapat dilihat pada Lampiran 4.

Berdasarkan sampel yang diambil dari 3 kolam masing masing 10 ekor ikan sampel yang masih hidup, kemudian dipilih dan diambil untuk pemeriksaan PCR. Hasil pemeriksaan KHV berdasarkan metode PCR dapat dilihat pada Gambar 5.3.

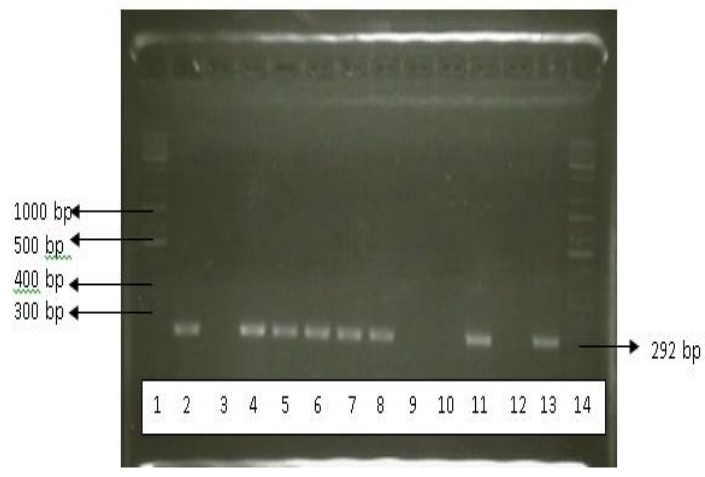

Gambar 3.3 Elektroforesis gel agarosa dari PCR diamplifikasi pada fragmen 292 bp dari KHV DNA yang diperoleh dari insang koi yang hampir mati. Primer yang digunakan untuk amplifikasi dipilih sesuai dengan OIE. Lane 1: Marker (100 bp DNA). Hasilnya, Lane 2 dan 13: kontrol positif; Lane 3 dan 12: kontrol negatif, Lane 4-8 hasil positif; Lane 9,10 hasil negatif

\section{Identifikasi Menggunakan Metode Immunofluorescence}

Hasil ekspresi positif virion KHV terlihat adanya pendaran pada daerah selnya. Hasil ekspresi negatif virion KHV tidak terlihat pendaran dari zat fluorophore.

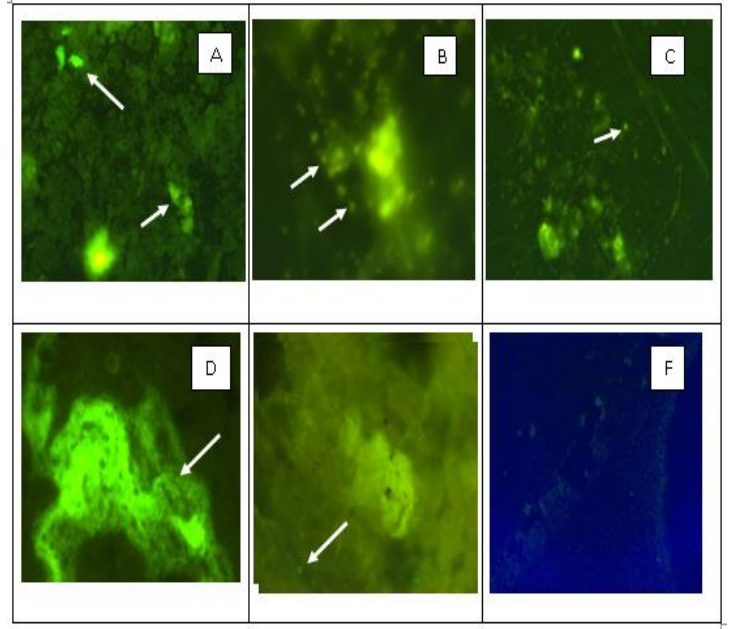

Gambar 3.4 Identifikasi KHV menggunakan monoclonal antibody anti-KHV dengan pewarnaan oleh zat fluorophore. Terlihat pendaran pada apusan suspensi organ insang, perbesaran 40x, (A) asal Malang. (B) asal Blitar. (C)Tidak terlihat pendaran pada apusan suspensi organ insang, perbesaran 40x. Terlihat pendaran pada apusan suspensi organ insang, perbesaran 100x, (D) sampel asal Malang, (E) sampel asal Blitar, (F) sampel asal Kediri (Mikroskop ultraviolet merk Zeiss). 


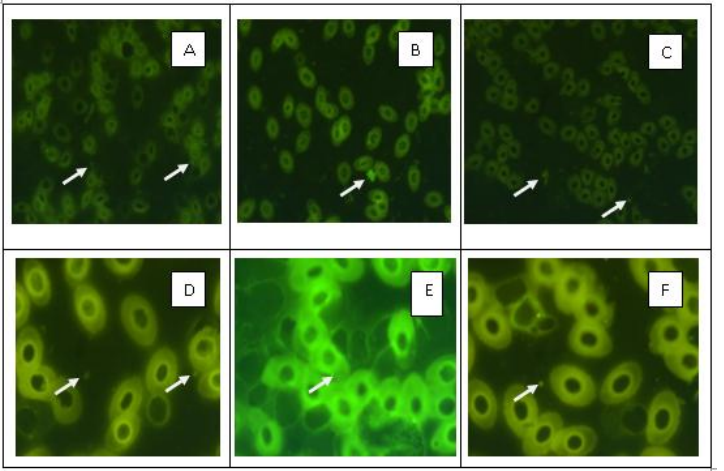

Gambar 3.5 Identifikasi KHV menggunakan monoclonal antibody anti-KHV dengan pewarnaan menggunakan zat fluorophore. A-C: Terlihat pendaran pada apusan darah; perbesaran 40x. D-F: Terlihat pendaran pada apusan darah; Perbesaran 100x (Mikroskop ultraviolet merk Zeiss)

\section{Identifikasi Menggunakan Metode Immunocytochemistry/ Imunositokimia}

Pengujian dilakukan dengan mendeteksi ada atau tidaknya protein KHV pada ikan koi dalam darah dan organ insang. Berdasarkan hasil pengujian yang telah dilakukan menggunakan metode ini, ditemukan hasil positif KHV pada gerusan insang dan whole blood sel. Hasil positif pemeriksaan Imunositokimia berwarna coklat keemasan dengan inti biru. Sedangkan Hasil negatif pemeriksaan Imunositokimia berwarna biru.

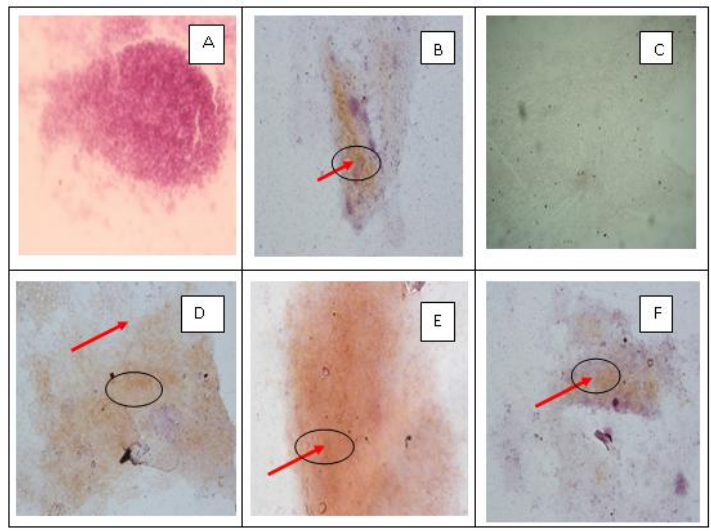

Gambar 3.7 Identifikasi KHV berdasarkan PCR positif menggunakan metode imunocytochemistry streptavidin biotin pada sediaan apus suspensi organ insang ikan koi. B,D,E,F: Terlihat ekspresi sampel positif KHV berwarna coklat keemasan. Perbesaran 100x. Mikroskop Olympus BX 51.

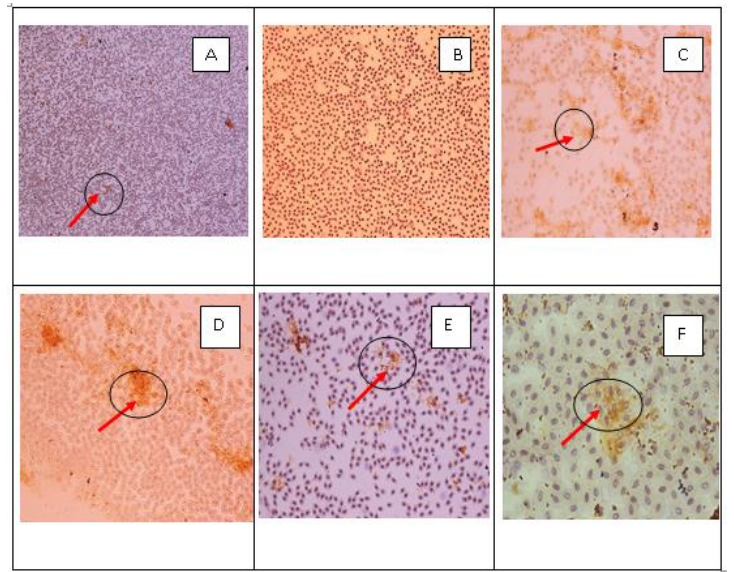

Gambar 3.8 Identifikasi KHVberdasarkan PCR positif menggunakan metode imunocytochemistry streptavidin biotin pada sediaan apus darah ikan koi. A dan C: Sampel dengan hasil Positif KHV terdapat ekspresi berwarna coklat keemasan. D, E dan F : Sampel dengan hasil Positif KHV terdapat ekspresi berwarna coklat keemasan; Perbesaran 100x. B: Sampel dengan hasil negatif tidak ada ekspresi; perbesaran. Mikroskop Olympus BX 51

Hasil pemeriksaan KHV dengan uji PCR sebagai konfirmasi awal diperoleh positif KHV sebanyak 5 sampel dari jumlah 10 sampel yang diambil yang selanjutnya dilakukan pemeriksaan dengan metode Immunofluorescence dan Immunocytochemistry asal Blitar dapat dilihat pada Tabel 2.

Tabel 3.2 Hasil uji KHV berdasarkan PCR positif dengan metode Immunofluorescence dan Immunocytochemistry asal Blitar, Malang dan Kediri 


\begin{tabular}{|c|c|c|c|c|c|c|}
\hline \multirow{2}{*}{$\begin{array}{l}\text { Asal } \\
\text { Sarpel }\end{array}$} & \multirow{2}{*}{$\begin{array}{l}\text { Jurtlah } \\
\text { Sampel }\end{array}$} & \multirow[t]{2}{*}{$P C R$} & \multicolumn{2}{|c|}{ Imuryofluoterscence (IF) } & \multicolumn{2}{|c|}{$\begin{array}{l}\text { Immunocytochemistry } \\
\text { (ImunositokimialiCC) }\end{array}$} \\
\hline & & & $\begin{array}{l}\text { Suspensi } \\
\text { organt }\end{array}$ & Darah & $\begin{array}{l}\text { Suspensi } \\
\text { ovgaul }\end{array}$ & Darah \\
\hline Blithy & 10 & Positif 5 & Positif 3 & Positif & Positif 4 & Positif \\
\hline Malang & 10 & Positif ? & Positif\} & Positif2 & Positif\} & Positif? \\
\hline Keditit & 10 & Positif 3 & Possitif 2 & Positif? & Positif 3 & Positif? \\
\hline
\end{tabular}

Ikan yang memiliki beberapa gejala klinis terinfeksi KHV, asal Blitar, Malang dan Kediri tersebut dilakukan uji PCR Polymerase Chain Reaction (PCR) merupakan suatu teknik sintesis dan amplifikasi DNA secara invitro yaitu menggunakan mesin yang bernama Thermalcycler. Alat ini dengan setting suhu dan siklus yang sesuai mampu melipat gandakan DNA. Jumlah siklus yang digunakan untuk proses PCR KHV adalah 30 siklus yang mana diharapkan mampu memperbanyak DNA secara eksponensial. Seperti yang telah dungkapkan oleh Handoyo, D et al tahun 2000 bahwa umumnya jumlah siklus yang digunakan pada proses PCR adalah 30 siklus. Penggunaan jumlah siklus lebih dari 30 siklus tidak akan meningkatkan jumlah amplicon secara bermakna dan memungkinkan peningkatan jumlah produk yang non-target. Perlu diingat bahwa di dalam proses PCR, effisiensi amplifikasi tidak terjadi $100 \%$, hal ini disebabkan oleh target templat terlampau banyak, jumlah polimerase DNA terbatas dan kemungkinan terjadinya reannealing untai target.

Virus KHV dengan komponen utamanya adalah protein yang diselubungi oleh kapsid masuk melalui insang sebagai pernapasan ikan. KHV akan menempel pada sel insang sebagai reseptor spesifik guna replikasi virus selanjutnya. Beberapa tahapan setelah tahap absorbsi, KHV juga akan melakukan tahap penetrasi, sintesis, pematangan yang selanjutnya tahap lisis yang dapat berlangsung secara cepat. Virus KHV dalam hal ini sebagai pathogen dapat memasuki aliran darah dan menyebar ke bagian lain dari tubuh ikan seperti dapat mengendap di ginjal dan tertelan lewat mulut masuk melalui sistem pencernaan yang akhirnya mengendap dan berkembangbiak di usus. Virus akan berenang mengikuti aliran darah selama ikan masih hidup dan mengikuti system aliran darah yang berfungsi sebagai alat transport. Virion dalam darah inilah yang diteliti guna melihat keberadaannya sebagai bentuk ekspresi melalui kedua metode yang ingin dikembangkan sebagai konfirmasi awal pemeriksaan sehingga mampu memberikan kontribusi dalam identifikasi virus KHV.

Dari beberapa jenis protein KHV yang bersifat antigenik mampu direaksikan berdasarkan ikatan antigen-antibodi. Antibodi yang digunakan bersifat spesifik dan komplemen terhadap antigen yang direaksikan. Monoklonal antibody memiliki binding site yang akan mengenali antigen tertentu dari beberapa jenis protein KHV tersebut. Dimana kedua interaksi ini akan membentuk suatu ikatan yang kuat ketika direaksikan.

Menurut Warsito, et al. 2013 mengungkapkan bahwa identifikasi KHV berdasarkan isolasi virus dan uji PCR mempunyai keterbatasan dalam hal sensitivitas sehingga diperlukan metode pendekatan diagnosis yang baru untuk peneguhan diagnosis KHV, yaitu uji imunopatologi imunositokimia dan imunofluorescence.

Alasan utama mencoba dikembangkannya metode ini adalah karena bersifat efektif dari segi waktu dan biaya, diakui secara internasional, mudah diaplikasikan pada masyarakat dan menurut Warsito,et al,2016 bahwa hal ini sangat diperlukan dalam rangka program kontrol dan pengendalian , termasuk pencegahan dan eradikasi KHV di Indonesia. Denga demikian, diharapkan akan mampu mengoptimalisasi kualitas dan peningkatan produksi hasil perikanan.

Sampel uji yang digunakan dalam penelitian ini adalah insang dan whole blood sel dari masing masing 10 sampel ikan koi yang berasal dari 3 wilayah berdasarkan anamnesis pernah mengalami wabah koi herpes virus. Meskipun ke tiga tempat tersebut pernah mengalami wabah KHV dengan angka morbiditas dan mortalitas yang relatif tinggi, 
tetapi sampai saat ini belum ada laporan belum ada wabah lagi didaerah tersebut.

$$
\text { Sampel yang didapatkan }
$$

diharapkan mampu memenuhi persyaratan dalam uji berbasis imunologis. Sampel uji dalam kondisi hidup ketika sampai di laboratorium diupayakan sedemikian rupa, Dalam hal ini tidak ada sampel yang mati diperjalanan karena penambahan oksigen secara periodik guna mempertahankan kondisi ikan. Hal ini diperkuat dengan alasan Wirata, et al. 2014 bahwa sampel rusak tidak dapat dilakukan uji imunokimia karena dikhawatirkan berpeluang meningkatkan kemungkinan hasil negatif palsu.

Suatu pemeriksaan darah sangatlah perlu pada keadaan patologis dan kita bisa mendapatkan pelengkap pemeriksaan. Susunan darah ikan merupakan faktor pemeriksaan penting, sehingga perubahan gambaran darah banyak digunakan untuk menilai status kesehatan ikan (Amrullah, 2004). Lestari, et al (2014) mengungkapkan bahwa darah merupakan salah satu media pembawa virus yang dapat menjangkau seluruh system organ, seperti saluran pencernaan, system pernafasan melalui sirkulasi darah.

Darah sebagai alat transportasi hemoglobin komponennya yaitu trombosit dan plasma darah sebagai pertahanan pertama dari serangan penyakit yang masuk ke dalam tubuh (Aria, 2008). Salah satu fungsi darah yaitu sebagai media transportasi dalam mengangkat/mengeluarkan zat-zat yang tudak berguna bagi tubuh untuk dikeluarkan melalui ginjal termasuk sumber penyakit, seperti bakteri, virus, maupun parasit.

Menurut Playfair, et al (2009) menyatakan bahwa insang sebagai reseptor spesifik KHV. Sedangkan kunci infeksi virus KHV bersasal dari replikaasi intra seluler yang dapat atau tidak dapat menimbulkan kematian sel. Oleh karena itu homogenisasi organ insang perlu dilakukan sehingga diperoleh antigen dalam bentuk suspense. Suspensi organ inilah yang kemudian didiagnosa dengan metode imunokimia.

\section{Uji immunofluorescence}

Uji Utama berdasarkan metode Immunofluorescence tak langsung sebagai pemeriksaan imunologis guna mendeteksi adanya antigen atau mencari lokalisasi antigen dalam jaringan insang dan dalam sel darah (sel specimen yang merupakan sekumpulan dari satu bagian atau lebih bahan yang diambil langsung dari suatu sistem dengan pewarnaan florescence. Dengan menggunakan metode tak langsung, imunofluoresensi menggunakan dua antibodi; yang berlabel pertama (primer) antibodi khusus mengikat molekul target setelah proses fiksas, antibodi sekunder yang dikonjugasikan dengan zat fluorophore tersebut akan mengikat antibodi primer tunggal. Hal ini akan memperkuat pengikatan jumlah molekul fluorophore per antigen. . Menurut Kresna, 2011 metode Immunofluorescence ini memiliki beberapa keunggulan antara lain bahwa metode ini merupakan metode yang cukup sederhana dan cepat untuk dilakukan dengan tingkat kepercayaan yang tinggi. Uji ini merupakan suatu metode untuk memeriksa adanya antibody atau antigen dengan menggunakan label fluorosence yang akan berpendar jika dilihat dibawah mikroskop ultraviolet.

\section{Uji Imunositokimia}

Pemeriksaan imunopatologi dengan metode imunositokimia yang diaplikasikan dalam peneguhan diagnosis penyakit KHV ini menggunakan teknik streptavidin biotin ini dengan alasan streptavidin ini memiliki kemampuan mengikat biotin yang sangat kuat yaitu memiliki berat molekul sebesar 60.000 dalton dan terdiri dari 4 subunit yang identik dengan setiap sub unit mempunyai satu bagian ikatan untuk biotin.(Warsito, et al. 2013). Hasil uji imunositokimia positif diamati di bawah mikroskop cahaya dan didasarkan pada analisis deskriptif terlihat adanya warna coklat keemasan setelah pada saat staining digunakan senyawa pembawa warna (kromogen) diamino-benzidine (DAB). Hal ini dipertegas oleh hasil penelitian Warsito dan Wuryastuti, 2011 menyatakan bahwa hasil akhir positif sediaan berwarna coklat muda sampai coklat 
tua ataupun berwarna coklat kemerahan/ keemasan.

\section{KESIMPULAN DAN SARAN}

\section{KESIMPULAN}

1. Metode Immunofluorescence yang diaplikasikan dalam penguatan identifikasi KHV dapat mendeteksi antigen KHV pada darah dan insang ikan koi (Cyprinus carpio).

2. Metode Immunocytochemistry yang diaplikasikan dalam penguatan identifikasi KHV dapat mendeteksi antigen KHV pada darah dan insang ikan koi (Cyprinus carpio).

\section{SARAN}

Perlu dikembangkan penelitian lebih lanjut tentang sensitifitas dan spesifitasnya serta pengujian terhadap suspensi organ lain seperti usus dan ginjal sebagai host spesifik lainnya menggunakan metode Immunofluorescence dan Immunocytochemistry.

\section{UCAPAN TERIMA KASIH}

Penulis haturkan terima kasih yang tidak terhingga kepada :

1. Sekolah Pascasarjana Universitas Airlangga yang telah memberi saya kesempatan untuk menempuh pendidikan S2 Bioteknologi Perikanan dan Kelautan.

2. Ibu Prof. Dr. Hj. Sri Iswati, S.E., M.Si., Ak. selaku Direktur Sekolah Pascasarjana Universitas Airlangga.

3. Bapak Prof Dr. Ir. Hari Suprapto, M.Agr. selaku koordinator ProgramStudi S2 Bioteknologi Perikanan dan Kelautan.

4. Bapak Prof. Dr. Suwarno, M.Si, drh selaku ketua Pembimbing Pertama Sekolah Pasca Sarjana, Surabaya, yang telah membimbing dan telah memberikan arahan, perhatian dan motivasi selama pengerjaan dan penyusunan tesis ini dengan penuh kesabaran.

5. Dr. Gunanti Mahasri, Ir., M.Si selaku pembimbing kedua yang telah memberikan arahan, bimbingan, petunjuk, saran serta motivasi penuh atas terselesainya tesis ini.

6. Dosen Penguji yang telah memberikan dukungan dan masukan atas terselesaikannya tesis ini.

7. Kantor Balai Karantina Ikan Pengendalian Mutu dan Keamanan Hasil Perikanan Kelas I Surabaya I yang telah menyediakan tempat untuk penelitian.

8. Kedua orang tuaku, Almarhum bapak Soermadji yang telah lama meninggal dan almarhumah ibu Sofia yang telah memberikan semangatnya serta do'a dan kepercayaan kepada penulis ketika dalam keadaan sakit selama proses tesis.

9. Suamiku Dandi, anak anak tercinta Helmi dan Randy, adik Irma yang bersedia membagi waktunya demi kelancaran tesis ini.

10. Teman-teman di Laboratorium Imunologi dan Biologi Molekuler yang penuh perhatian dan selalu setia mendengar keluh kesah penulis.

11. Teman-teman S2 Biotek Almira, Lina, Widya, Akbar, mas Anggi, Mbak Ayu, Rahma Umami, Mbak Myrna, Mba Ica, Pak Laode, Pak Ricat dan Pak Ferry yang selalu membantu dan memotivasi penulis.

12. Semua pihak yang telah mendukung hingga selesainya Tesis ini.

\section{DAFTAR PUSTAKA}

Ariel, E. 2005. Ornamental fish as transboundary vectors of viral diseases. In P. Walker, R. Lester and M.G. Bondad-Reantaso(eds). Diseases in Asian Aquaculture V, pp. 103-112. Fish Health Section, Asian Fisheries Society, Manila. 
Bachtiar. 2002. Mencemerlangkan Warna Koi. Tim Lentera. Agro Media Pustaka. 74 hal.

Bercovier H, Fishman Y, Nahary R, Sinal S, Ziotkin A, Eyngor M, Gilad O, Eldar A, Hedrick RP 2005. Cloning of the Koi Herpesvirus (KHV)Gene Encoding Thymidine Kinase and Its Use for a Highly Sensitive PCR Based Diagnosis. BMC Microbiol 5:13-19.

Berti Anina, dkk. 2014. Laporan Praktikum Kuliah Lapangan Taksonomi Vertebrata di LIPI. Pendidikan Biologi Fakultas Tarbiyah dan Keguruan Institut Agama Islam Negeri Raden Intan. Lampung.

Boenich,T., A.J Farmilo, Ronald H. Stead, Marc Key, Rosanne Welcher, Richard Harvey, Keren N. Atwood. 2001. Hand Book Immunochemical staining Method Edisi-3. Daco Dytomation, Carpinteria. California.

Breeder Koi. 2009. Bentuk Badan Ikan Koi. http://www.Solat-Aid.org. Diakses pada 31 Juli 2015, jam 08.00 WIB

Cahyono, B. 2000.Budidaya Ikan Air Tawar Ikan Gurami, Ikan Nila, Ikan Mas.Kanisius.Yogyakarta.113 hlm.

Campbell, Mitchell, Reece (2002). Biology:Edisi V Jilid 3, Jakarta: Erlangga.

Cobo F. 2012. Application of Molecular Diagnostic Techniques for Viral Testing. The Open Virology Journal. Vol. 6: 104-114.

Departemen Budidaya. 2005. Biologi Reproduksi dan Pengendalian dalam Upaya Pembenihan Ikan Koi (Cyprinus carpio). Institute Pertanian Bogor.

Dishon A, Davidovich M, Ilouze M, Kotler M. (2007). Persistence of cyprinid herpesvirus 3 in infected cultured carp cells.J Virol81: 4828-4836.

D. POKOROVA, T. VESELY, V. PIACKOVA, S. RESCHOVA , J. HULOVA. 2005. Current Knowledge on Koi Herpesvirus (KHV). Vet. Med. - Czech, Veterinary Research Institute, Brno, Czech Republic.University of South Bohemia in Ceske Budejovice, Research Institute of Fish Cultureand Hydrobiology in Vodnany, Czech Republic.

Edi, S. dkk. 2010. Identifikasi Infeksi Koi Herpes Virus (KHV) pada Ikan Koi (Cyprinus carpio) dengan Metode Polymerase Chain Reaction (PCR), Imunositokimia dan Imunohistokimia. Indonesian Journal of Veterinary Science \& Medicine. Vol I Nomor 2: 17-22.

Effendy, Hersanto. 1993. Mengenal Beberapa Jenis Koi. Kanisius. Yogyakarta.

Efik Yuli Peryuni. 2013. Ikan Koi, jenis-jenis dan daftar harga. http://ikanhiasyuli.blogspot.com/2014/02/ikankoi.html. Journal of Virologi. 2007 May; 81(10): 5058-5065. Published online 2007 Feb 28. doi: 10.1128/JVI.00146-07PMCID: PMC1900211

Euis Laelawati. 2008. Respon Tanggap Kebal Ikan Mas (Cyprinus carpio) Terhadap Vaksin Koi Herpesvirus yang diberikan melalui Injeksi dengan Dosis Berbeda. Program Studi Teknologi Manajemen Akuakultur, Fakultas Perikanan dan Ilmu Kelautan IPB. 2008

Fauzi Faruza. 2015. Teknik Diagnosa Penyakit Ikan.

http://www.academia.edu/4876626/TE KNIK_DIAGNOSA_PENYAKIT_IK AN. Diakses tanggal 17 April 2015. 
Handoyo E dan Rudiretna A. 2001. Prinsip Umum dan Pelaksanaan Polymerase Chain Reaction (PCR). Unitas. Vol. 9. No. 1.

Hatem Soliman and Mansour El-Matbouli. 2005.An Inexpensive and Rapid Diagnostic Method of Koi Herpesvirus (KHV) Infection by Loop-Mediated Isothermal Amplification Virology.Journal Open Access Methodology.Published: 17 October 2005. This article is available from: http://www.virologyj.com/content/2/1/ $\underline{83}$ (C) 2005 Soliman and El-Matbouli; licensee BioMed Central Ltd.

Isti Koesharyani, dkk. 2001. Manual For Fish Disease Diagnosis- II. Gondol Research. Research Institute For Mariculture and JICA.

Jean-Christophe Avarrea, Jean-Paul Madeiraa, Ayi Santikab, Zakki Zainunb, Marine Baudc, Joëlle Cabonc, Domenico Carusoa, Jeannette Castric c, Laurent Bigarréc. 2011. Investigation of Cyprinid herpesvirus-3 genetic diversity by a multi-locus variable number of tandem repeats analysis. Journal of Virological Methods 173 (2011) 320-327. Journal of Virological Methods. Journal homepage:

www.elsevier.com/locate/jviromet.

Keputusan Menteri Kelautan dan Perikanan. 2013. Penetapan Jenis-Jenis Hama dan Penyakit Ikan Karantina, Golongan, Media Pembawa dan Sebarannya. Keputusan Menteri Kelautan dan Perikanan Nomor 26/KepmenKP/2013.

Khairruman, Dodi S. dan Bambang G. 2008.Budidaya Ikan Mas Secara Intensif. Agromedia Pustaka. Jakarta. $100 \mathrm{hlm}$.

Kimiko Uchii, Arndt Telschow, Toshifumi Minamoto,
Hiroki Yamanaka, Mie N Honjo, Kazuaki Matsui and Zen'ichiro Kawabata. 2010. Transmission dynamics of an emerging infectious disease in wildlife through host reproductive cycles.Correspondence: K Uchii, Department of General Systems Studies, University of Tokyo, 3-8-1 Komaba, Meguro, Tokyo 153-8902, Japan. E-mail: c-uchii@mail.ecc.utokyo.ac.jp. Current address: $\mathrm{H}$ Yamanaka, Department of Environmental Solution Technology, Ryukoku University, Otsu, Japan.

KKP. 2012. Industrialisasi Perikanan Budidaya. Arsib Berita Perikanan. Umm.ac.id. Universitas Muhammadiyah Malang. $2 \mathrm{hlm}$

Koi4u. 2008. Stability of colours. Published on Monday, 24 November 2008 12:16 . Website Last Modified: Saturday 31 January 2015.

Konishi Koi Farm. 2015. Koi Herpes Virus.Konishi Koi Farm. http://www.konishikoi.com/kh/index.p $\mathrm{hp}$

Kunin CM. 1997. Detection, prevention and management of urinary tract infection 3th. Ed. Lea. Febiger, Philadelphia.

Lestari, Artanti Tri dan Putu Eka Sudaryatma. 2014. Studi Imunositokimia Darah dan Suspensi Organ Kerapu Macan (Ephinephelus fuscoguttatus) yang Diinfeksi Virus Isolat Lapang Penyebab Viral Nervous Necrosis. Jurnal Sain Veteriner ISSN : 01260421.

Lio-Po, G., et. al. 2009. Surveillance of Emerging Fish Viral Pathogens in Some Southeast Asian Countries. The Israeli Journal of AquacultureBamidgeh 61(3): 208-214.

Malole.2005. Bahan Teori dan Praktikum Apresiasi Teknik Virologi dan PCR 
Penyakit Hewan Aquatik. Balai Besar Karantina Ikan Soekarno-Hatta. Jakarta.

Mashuri Masri Dosen pada Jurusan Biologi Fakultas Sains. DETEKSI KOI HARPES VIRUS (KHV) PADA IKAN MAS KOI (Cyprinus carpio L) DENGAN MENGGUNAKAN METODE APLIKASI Polymerase Chain Reaction (PCR). Teknologi UIN Alauddin Makassar. Jurnal Teknosains,Volume 7 Nomor 2, Juli 2013, hlm: 189 - 200.

Michel, Leroy, Stalin Raj, Liefrigg, J.Mast, Wattiez, A.F Vanderplasschen and B. Costes. 2010. The Genome of Cyprinid Herpesvirus 3 Encodes 40 Proteins Incorporated in Mature Virions. Journal of General Virilogy: 452-462. Belgium

Mohammad, F. 2009. Histopathological Studies on Tilapia zilli and Solea vulgaris from Lake Qarun, Egypt. Journal of Fish and Marine Science 1 (1):29-39,2009.

Narbuko, C dan Achmadi. 2001. Metode Penelitian. Bumi Aksara. Jakarta.

Narisah, Putri. 2015. Koi Herpes Virus (KHV). http://www.academia.edu/4777446/Ko i Herpes Virus. Diakses tanggal 20 November 2015.

Nazir, M. 1985. Metodologi Penelitian. Ghalia. Jakarta.

O.L.M. Haenen, K. Way, S.M. Bergmann and E. Ariel. 2004. The Emergence of Koi Herpesvirus and Its Significance to European Aquaculture. Bull. Eur. Ass. Fish Pathology.

O.L.M. Haenen, K. Way, S.M. Bergmann and E. Ariel. 2004.The emergence of koi herpesvirus and itssignificance to European aquacultureBull. Eur. Ass. Fish Pathol.
Perelberg, A., M. Smirnov, M. Huttoran, A. Diamant, I. Bejerano, and M. Kotler. 2003. Epidemiologycal Description of an New Viral Disease Afflivting Cultured Cyprinus Carpio in Israel. The Israel Journal of Aquaculture Bamidgeh 55:5-12.

Prihartono, Eko. 2004. Permasalahan Ikan Koi dan Solusinya. Penebar Swadaya. Jakarta.

Pikulkaew S. et al.2009. The Outbreak of Koi Herpesvirus (KHV) in Koi (Cyprinus carpio koi) /Thai J. Vet. Med. 39(1): 53-58. 53 from Chiang Mai Province, Thailand.

Pikarsky, E., Ronen, A., Abramowitz, J., Levavi-Sinan, B., Hutoran, M., Shapira, Y., Steinetz, M. Perelberg, A., Soffer, D., and Koller, M. 2004.Pathogenesis of Acute Viral Disease Induced in Fish by Carp Interstitial Nephritis and Gill Necrosis Virus. Journal of Virology, 78:95549551.

Playfair, J.H.L. dan B.M. Chain. 2009. At a Glance Imunologi. Edisi Kesembilan. Penerbit Erlangga.

Priyambodo.2001. Deteksi Bakteri Berselubung Antibodi Dalam Sedimen Air Kemih Dengan Uji Streptavidin Biotin. Program Pascasarjana Universitas Airlangga. Surabaya.

Rantam,Dr. Fedik.A, drh. 2003. Metode Imunologi. Airlangga University Press. Surabaya.

Raden Wasito, Hastari Wuryastuti, Bambang Sutrisno. 2013. Identifikasi Koi Herpesvirus dengan Uji Imunopatologi Imunohistokimia Streptavidin Biotin pada Ikan Mas Karier (IDENTIFICATION OF KOI HERPESVIRUS USING IMMUNOPATHOLOGIC IMMUNOHISTOCHEMISTRY OF STREPTAVIDIN BIOTIN IN THE 
Jurnal Biosains Pascasarjana Vol. 18 (2016) pp

(C) (2016) Sekolah Pascasarjana Universitas Airlangga, Indonesia

COMMON CARP CARRIERS). Bagian Ilmu Penyakit Dalam, Fakultas Kedokteran Hewan Universitas Gadjah Mada. Jurnal Veteriner Maret 2013. Vol. 14 No. 1: 37-44. ISSN: $1411-8327$

Ragam Fauna. 2015. Ini 13 Gambar Jenis Ikan Koi. http://www.duniaq.com/ini-13gambar-jenis-ikan-koi/. Diakses tanggal20 Nopember 2015.

Subagyo, M. 1991. Metode Penelitian dalam Teori dan Praktek. Bumi Aksara. Jakarta.

Suryabrata. 1997. Metode Penelitian. Raya Grafindo Persada. Jakarta

Susanto, Heru. 2000. Koi. Penebar Swadaya. Cipondoh.

Suprapto, H. 2011. Histologi Ikan. Fakultas Perikanan dan Kelautan Universitas Airlangga. Surabaya. Hal 6-13.

Sano, M. Crane, M., komar, C. 2004. Infection With Koi herpesvirus-Disease Carp, Developed To Support the NACA/FAO/OIE regional quarterly aniamal disease reporting system in NACA. Bangkok. Thailand. 11 pp.

Savni. 2014. Histopatologi Ikan Mas (Cyprinus carpio). Laporan Praktikum ke-13 mata kuliah Penyakit Organisme Akuatik. Departemen Budidaya Perairan Fakultas Perikanan dan Ilmu Kelautan Institut Pertanian Bogor.

Sunarto, A., Taukhid, Rukyani, A., Koesharyani, I., Supriyadi, H., Huminto, H., Agungpriyono, D.R., Pasaribu, F.H., Widodo, Herdikiawan, D., Rukmono, D., Prayitno, S.B., 2002. Field investigations on a serious disease outbreak among koi and common carp (Cyprinus carpio) in Indonesia. In: 5th Symposium on Diseases in Asian Aquaculture, Gold Cost, Australia.
Takashi Aoki, Ikuo Hirono,Ken Kurokawa, Hideo Fukuda,Ronen Nahary,Avi Eldar, Andrew J. Davison, Thomas B. Waltzek,Herve Bercovier,and Ronald P. Hedrick 2012. Genome Sequences of Three Koi Herpesvirus Isolates Representing the Expanding Distribution of an Emerging Disease Threatening Koi and Common Carp Worldwide. This article has been cited by other articles in PMC. Manual of Diagnostic Tests for Aquatic Animals 2012

Taukhid, A., Sunarto, A., Koesharyani, I., Supriyadi, H., Gardenia. 2004. Strategi Pengendalian Penyakit Koi Herpesvirus (KHV). Balai Riset Budidaya Air Tawar.

Takashi Aoki,Tomokazu Takano, Sasimnanas Unajak, Madoka Takagi, Young Rim Kim, Seong Bin Park, Hidehiro Kondo, Ikuo Hirono, Tatsuo SaitoTaki, Jun-ichi Hikima, Tae Sung Jung. 2010. Generation of Monoclonal Antibodies Specific for ORF68 of Koi Herpesvirus. Laboratory of Genome Science, Tokyo University of Marine Science and Technology, 4-5-7 Konan, Minato, Tokyo 108-8477, Japan. Department of Microbiology, School of Allied Health Science, Kitasato University, Sagamihara, Kanagawa 228-8555, Japan. Aquatic Biotechnology Center, College of Veterinary Medicine, Gyeongsang National University, 900 Gajwa-dong, Jinju, Gyeongnam 660-710, South Korea.

Takashi Aoki, Ikuo Hirono, Ken Kurokawa, Hideo Fukuda, Ronen Nahary, Avi Eldar, Andrew J. Davison, Thomas B. Waltzek, Herve Bercovier, and Ronald P. Hedrick. 2007. Genome Sequences of Three Koi Herpesvirus Isolates Representing the Expanding Distribution of an Emerging Disease Threatening. Koi and Common Carp Worldwide. JOURNAL OF 
Jurnal Biosains Pascasarjana Vol. 18 (2016) pp

(C) (2016) Sekolah Pascasarjana Universitas Airlangga, Indonesia

VIROLOGY, May 2007, p. 50585065 Vol. 81, No. 10. Copyright (C) 2007, American Society for Microbiology. All Rights Reserved.

Uchii K, Telshow A, Minamoto T, Yamanaka H, Honio MN, Matsui K, Kawabata Z. .2010. Transmission Dynamics of an Emerging Infectious Disease in Wildlife Through Host Reproductive Cycles. The ISME Journal (2011) 5, 244-251; doi:10.1038/ismej.2010.123; published online 26 August 2010.

Wirata,K., Ketut Berata dan Ketut Puja. 2014. Sensitifitas dan Spesifisitas Teknik Imunohistokimia Rabies. Balai Besar Veteriner Denpasar. Jurnal Ilmu dan Kesehatan.

Warsito, R., Hastari, W., Bambang, S. 2013. Identifikasi KHV Dengan Uji Imunopatologi Imunohistokimia Streptavidin Biotin Pada Ikan Mas Karier. Jurnal Veteriner 14. No. 1: 37 44.

Warsito, R dan Hastari Wuryastuti. 2014. Antibodi dan Imunohistokimia. Rapha Publishing. Yogyakarta.

Yunasfi. 2006. Faktor-Faktor Yang Mempengaruhi Perkembangan Penyakit Dan Penyakit Yang Disebabkan Oleh Jamur. Fakultas Pertanian Universitas Sumatera Utara. 